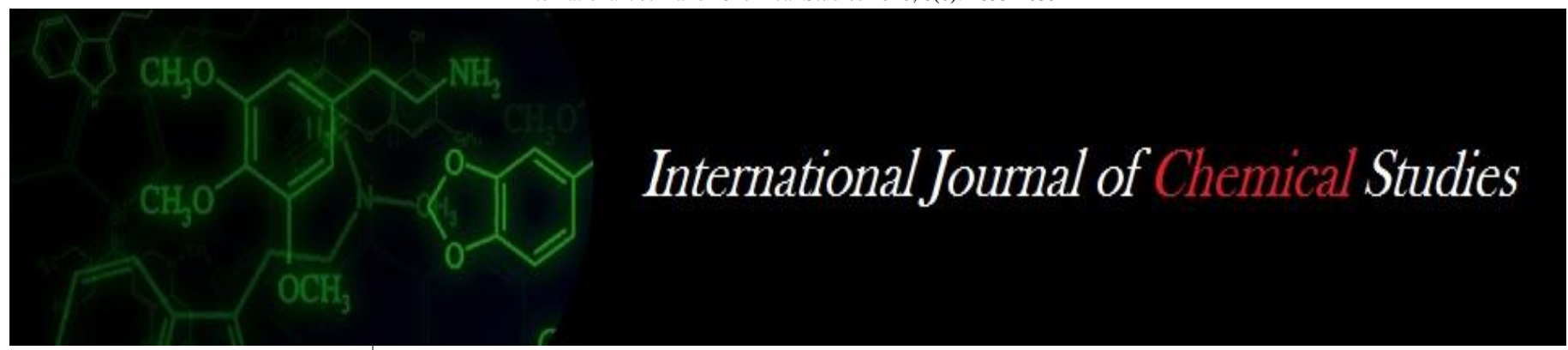

P-ISSN: 2349-8528

E-ISSN: 2321-4902

www.chemijournal.com

IJCS 2020; 8(6): 2833-2835

(C) 2020 IJCS

Received: 14-09-2020

Accepted: 28-10-2020

Neha Chauhan

Department of Textile and

Apparel Designing, I.C. College

of Home Science, CCSHAU,

Hisar, Haryana, India

Nisha Arya

Department of Textile and

Apparel Designing, I.C. College

of Home Science, CCSHAU,

Hisar, Haryana, India

\section{Study on modification of properties of cotton Khadi fabric by enzymatic treatment}

\author{
Neha Chauhan and Nisha Arya
}

DOI: $\underline{\text { https://doi.org/10.22271/chemi.2020.v8.i6an.11265 }}$

\begin{abstract}
Introduction of enzyme in textile processing has brought a major contribution towards textile processing specially textile wet processing. Conventionally wet processed products have a lot of limitations that can be resolved by using enzymes in processing. Enzymes are present in living organisms but are not living themselves. Enzymes are very mild components in the environment. Enzymes act as a molecular worker offering an answer to the desire for a cleaner gentler less polluting and hyper genic chemistry with minimum damage to textile substrate and the environment. Present investigation was aimed to study the effect of enzymatic agents on cotton khadi fabric. Enzymatic treatment was given in different combinations and the treated fabric was assessed in terms of hand feel and appearance.
\end{abstract}

Keywords: Enzyme, environment, substrate, textile, treatment

\section{Introduction}

Khadi is a sacred cloth according to M.K. Gandhi. Gandhiji presented khadi as a symbol of nationalism, equality and self-reliance. It was his belief that reconstruction of the society and effective Satyagraha against the foreign rule can be possible only through khadi. Khadi is the central core of the constructive activities as recommended by him. According to him there could be no swaraj without universal and voluntary acceptance of khadi. In his words, "I am a salesman of swaraj. I am a devotee of khadi. It is my duty to induce people, by every honest means, to wear khadi" (Joshi, 2002) ${ }^{[3]}$.

Khadi or khaddar refers to varieties of coarse cloth made out of cotton, wool, silk and their blends, which have been hand woven using hand spun yarn. Khadi can be deliberated as the vocal evocative of the Indian cottage Industry. Khadi fabric is made by manually spinning the threads on the charkha and weaving the fabric by hand. The process of hand spinning and weaving leads to the unique rugged texture of the khadi fabric. Khadi fabric has its own sole hand and feel. There are many attributes associated with khadi, in particular cotton khadi. It keeps wearer cool in summer and warm in winter. Its weave structure allows ample amount of air to pass over and around the body. It has capacity to absorb moisture. It is $100 \%$ natural and therefore, not harmful to skin as compared to manmade synthetic fabrics (Rastogi et al., 2015) [7, 8]. In the former period Khadi fabric was associated with politicians' and was considered to be poor man's clothing. But with the shifting era, the fabric is emerging as the fashion fabric with the shifted designers' interest in apparels and is now tantamount with designer wear. However, the unique hand of the fabric limits its use. As there are two sides of a coin, khadi also has drawbacks associated with it as cotton khadi is prone to get wrinkled easily, poor color fastness, drapability, higher maintenance cost etc. Drape is the most important aesthetic property of fabrics, garments and other textile structures. Fabric drape can be defined as a description of the deformation of the fabric produced by gravity when only part of it is directly supported. This unique characteristic provides a sense of fullness and a graceful appearance that distinguishes fabrics from other sheet materials. Ability of fabric to all under its own weight into wavy folds is called drapeability. The drape relieves monotony of shape and enhances the beauty of garment and its appreciation.

In today's world of modernization and industrialization, tastes and preferences of consumers are changing rapidly, so there is a need to bring innovative changes and new designs in clothing. Khadi industry is also under continuous pressure to meet growing consumer's aspiration and demand through constant product innovation, improved quality and
Neha Chauhan

Department of Textile and

Apparel Designing, I.C. College

of Home Science, CCSHAU,

Hisar, Haryana, India 
competition. Today's consumer demands well-fitted, comfortable, and easy to care garments, which can be washed and worn (Pant and Jain, 2014) ${ }^{[6]}$. With the modernization and the growing demand of suitable fabric hand and drape for each dress design, the need for modification and enhancement of the khadi fabric arises to cater the demand. The properties of the khadi fabric can be altered using different form of softening and finishing agents.

The use of synthetic and traditional finishing agents for the modification of textile materials such as chlorine or its derivatives, chlorine-Hercosett treatment, and hypochlorite chlorine has big disadvantages of negative environmental impacts including disposal of absorbable organic compounds. with the increase of ecological restrictions on the release of textile industrial effluents, there is a need for developing environmentally favourable alternatives for textile treatment processes. Introduction of enzyme biotechnology in textile industrial processes is gaining more and more interest due to their ability to operate under very mild conditions and therefore, processes are safer in terms of degradation to fibre and are biodegradable and substitute the harmful chemicals and thus reduce the effluent load.

The term 'Enzyme' came from the Greek word 'Enzymos' means 'In the cells or Ferments'. These are naturally available, high molecular weight proteins, capable of catalyzing chemical reaction of biological process and therefore popular as 'Biocatalyst'.

Enzymes are soluble organic substance, produced by living organisms whose different amino acids form long poly peptide chains (-HN-R-CONH-R-CO-) $\mathrm{n}$ by condensation polymerization. Biological desizing, souring, and bleaching of cotton fabric improve the performance in terms of surface wettability, stiffness, tensile strength, loss in fabric weight, whiteness index, and increased dye absorbance, and results are found very much comparable or superior to those treated through chemical conventional methods. Das, observed that cotton fabric treated with enzymes possess better hand feel than the one treated with traditional method (Rastogi and Pant, 2015) ${ }^{[7,8]}$.

It is on the basis of the above context that the present work was planned. Cotton khadi fabric was treated with different enzyme combinations and studied for their appearance and hand feel.

\section{Objective}

To study the effect of selected enzymes on the hand feel and appearance of cotton khadi fabric.

\section{Materials and Methods}

1. Procurement of fabric: A survey was conducted in the local market of Hisar, Delhi, Panipat and Jind to procure cotton khadi fabric. On the basis of visual inspection, pure cotton khadi fabrics suitable for the research work were collected. The collected fabrics were screened depending upon their texture, hand, evenness and compactness of the weave and uniformity of yarn. Cotton khadi fabric exhibiting medium weight was selected for the study and was procured from Khadi India, Jind, Haryana. The selected fabric was subjected to burning, physical and chemical tests for conformation of purity.

2. Procurement of enzymes: For increasing absorbency of the cotton khadi fabric, enzymatic desizing treatment was given using EBZYME AMYLASE and enzymatic scouring was done with EBZYME PECTINASE (Verma 2017). For imparting enzymatic softening EBZYME CELLULASE, EBZYME XYLANASE and EBZYME LIPASE, selected on the basis of review were procured from Enzyme Bioscience Private Limited, Surat

3. Pretreatment of the Cotton khadi fabric: To ensure complete wetting and uniform absorbency of the softening agents, the cotton khadi fabric was subjected to preparatory process. Desizing and scouring treatments were given to the fabric to remove foreign materials before imparting the finish.

4. Enzymatic desizing and scouring: The cotton khadi fabric was desized with 2.5 percent on weight of fabric (owf) EBZYME AMYLASE at $60^{\circ} \mathrm{C}$ for 1 hour with material to liquor ratio $1: 20$ by maintaining the $\mathrm{pH}$ at 7 . The treatment liquor was drained out and the fabric was given one hot and one cold wash. Then the fabric was dried and weighted. After desizing, the fabric was scoured in a bath containing 2 per cent (owf) EBZYME PECTINASE at $60^{\circ} \mathrm{C}$ temperature with $1: 15$ material to liquor ratio at $7 \mathrm{pH}$ for 60 minutes. The fabric was rinsed in hot and cold water and dried on a flat surface (Verma 2017).

\section{Results and Discussion}

The selection of enzymes was done after considering their suitability for application on cotton khadi fabric on the basis of available literature. Hence, three enzymes extracted by Aspergillus spp. i.e., EBZYME CELLULASE having enzyme activity 45000 EBU/gm, EBZYME XYLANASE having enzyme activity $25000 \mathrm{EBU} / \mathrm{gm}$ and EBZYME LIPASE having enzyme activity $25000 \mathrm{EBU} / \mathrm{gm}$ were selected, based on review. Further, eighteen different combination ratios of enzymes were tried for the study.

The preference of experts for 18 different applied combinations of enzymes on parameters of hand feel and appearance is elucidated in Table 16 and Fig. 4. The enzyme combination of $80 \%+10 \%+10 \%$ Cellulase + Xylanase + Lipase ranked I in the list with weighted mean score 4.3 (hand feel) and 4.5 (appearance). This was followed by $100 \%$ Cellulase which ranked II for hand feel with weighted mean score 4.1. The enzyme combination $80 \%+20 \%$ Cellulase + Lipase ranked II in appearance with weighted mean score 4.0. Similarly, the combination of $60 \%+20 \%+20 \%$ Cellulase + Xylanase + Lipase got III rank with weighted mean score 3.8 (hand feel) and 3.5 (appearance).

Hence, enzyme combination of $80 \%+10 \%+10 \%$ Cellulase + Xylanase + Lipase was finalized for further research work.

Table 1: Selection of enzyme combination for softening treatment of cotton khadi fabric

\begin{tabular}{|c|c|c|c|c|c|}
\hline S. No. & Combinations & \multicolumn{2}{c|}{ Hand feel } & \multicolumn{2}{c|}{ Appearance } \\
\hline & & WMS & Rank & WMS & Rank \\
\hline & $100 \%$ Cellulase e & 4.1 & II & 3.4 & IV \\
\hline & $100 \%$ Xylanase & 2.6 & XI & 2.9 & VIII \\
\hline & 100\% Lipase & 2.5 & XII & 2.7 & X \\
\hline & 50+50 Xylanase + Cellulase & 3.1 & VI & 2.4 & XIII \\
\hline
\end{tabular}




\begin{tabular}{|c|c|c|c|c|c|}
\hline & 50+50 Cellulase + Lipase & 3.5 & V & 2.7 & X \\
\hline & 80+20 Cellulase + Xylanase & 3.6 & IV & 4 & II \\
\hline & 80+20 Cellulase + Lipase & 3.6 & IV & 3.4 & IV \\
\hline & 80+20 Xylanase + Lipase & 2.4 & XIII & 2.5 & XII \\
\hline & 80+20 Xylanase + Cellulase & 3.0 & VIII & 3.2 & V \\
\hline & 80+20 Lipase + Cellulase & 2.9 & IX & 2.6 & XI \\
\hline & 80+20 Lipase + Xylanase & 1.9 & XVI & 3.1 & VI \\
\hline & 60+20+20 Lipase + Cellulase + Xylanase & 2.8 & X & 2.8 & IX \\
\hline & 60+20+20 Xylanase + Lipase + Cellulase & 3.0 & VII & 3.0 & VII \\
\hline & 60+20+20 Cellulase + Xylanase +Lipase & 3.8 & III & 3.5 & III \\
\hline & 80+10+10 Lipase + Cellulase + Xylanase & 1.9 & XVI & 2.3 & XIV \\
\hline & 80+10+10 Xylanase + Lipase + Cellulase & 2.0 & XV & 2.6 & XI \\
\hline & 80+10+10 Cellulase + Xylanase + Lipase & 4.3 & I & 4.5 & I \\
\hline
\end{tabular}

\section{Conclusion}

Biotechnology finds wide application in textiles and it will prove to be a boon to the ever-changing conditions of the ecology as well as economy. Pollution free processes are gaining ground all over the world. In this scenario, enzymes emerging as the best alternative to the polluting textile processing methods. In textile processing the enzyme can be successfully used for preparatory and finishing process like desizing, scouring and bleaching and is appropriate to create a cleaner and greener environment and product too. Enzymes are not only beneficial from ecological point of view but they are also saving lot of money by reducing water and energy consumption which ultimately reduce the cost of production. It seems that in the future it will be possible to do every process using enzymes.

\section{References}

1. Dixit S. Improvement in physical properties of khadi cotton fabric through pretreatment with swelling agent ethylenediamine. International Journal of Applied Research 2016;2(5):806-809.

2. Hoque SMA, Azim AYMA. Using Enzymes as an Aid of Better and Eco-Friendly Scouring Processing. American journal of Engineering Research 2016;5(6):167-182.

3. Joshi D. Gandhiji on KHADI, Meghshaym T. Ajgaonkar, Executive Secretary Mani Bhavan Gandhi Sangrahalaya 19, Laburnum Road, Gamdevi, Mumbai 2002, 3.

4. Mojsov K. Application of Enzymes in the Textile Industry: A Review. II International Congress Engineering, Ecology and Materials in the Processing Industry 2011;1(17):230-239.

5. Namrata M, Naik D. Effect of Bio-finishes on Designer's Naturally Coloured Cotton Khadi Stripe Fabrics. IOSR Journal of Polymer and Textile Engineering 2014;1(3):30-36.

6. Pant S, Jain R. Comfort and Mechanical Properties of Cotton and Cotton Blended Knitted Khadi Fabrics. Stud Home Com Sci 2014;8(2-3):69-74.

7. Rastogi S, Pant S. Study on modification of Physical Properties of Khadi Fabrics by Enzymatic Treatment. Studies on Home Community Sciences 2015;9(2,3):6578.

8. Rastogi S, Pant S, Agarwal A. Effect of different softening agents on khadi. International Journal of Engineering Research and Applications 2015;5(4):55-60.

9. Shah SR. Chemistry and Application of Cellulase in Wet Textile Processing. Research journal of Engineering and Sciences 2013;2(7):1-5. 